Cahiers $d u$ MONDE RUSSE

\section{Cahiers du monde russe}

Russie - Empire russe - Union soviétique et États indépendants

$53 / 2-3 \mid 2012$

L'invention de la Sainte Russie

\title{
ДВА ЭТАПА ДИСЦИПЛИНАРНОЙ РЕВОЛЮЦИИ В РОССИИ XVII И XVIII СТОЛЕТИЯ
}

Deux étapes de la révolution disciplinaire en Russie, XVII ${ }^{e}$-XVIII ${ }^{e}$ siècles The two stages of disciplinary revolution in Russia: the seventeenth and eighteenth centuries

\section{Виктор Живов}

\section{(Q) OpenEdition}

\section{Journals}

Édition électronique

URL : http://journals.openedition.org/monderusse/9386

DOI : $10.4000 /$ monderusse.9386

ISSN : $1777-5388$

Éditeur

Éditions de l'EHESS

Édition imprimée

Date de publication : 15 septembre 2012

Pagination : 349-374

ISSN : $1252-6576$

\section{Référence électronique}

Виктор Живов, « Два этапа дисциплинарной революции в России XVII и XVIII столетия », Cahiers du monde russe [Онлайн], 53/2-3 | 2012, Выложить онлайн 01 juillet 2015, Наводить справки в 01 mai 2019. URL : http://journals.openedition.org/monderusse/9386 ; DOI : 10.4000/monderusse.9386 
$\mathrm{Au}$ moment où nous mettions son article sous presse, nous avons eu la tristesse d'apprendre la mort de Viktor Živov, décédé le 17 avril 2013, à Berkeley, à l'âge de 68 ans. Né à Moscou en 1945, Viktor Živov a fait ses études au département de philologie à l'université Lomonossov de Moscou où il a soutenu, en 1992, une thèse de doctorat en liguistique structurale et où il a été professeur jusqu'en 2001. Il a également travaillé à l'Institut de la langue russe à Moscou et a été, depuis 1995, professeur à l'université de Californie à Berkeley. Chercheur inventif en même temps que rigoureux, auteur de dix livres et de nombreux articles dans les domaines de la linguistique et de l'histoire de la langue russe, Victor Živov transformait l'histoire de la langue en une partie intégrante non seulement de l'histoire littéraire et culturelle, mais aussi de l'histoire socio-politique et religieuse de la Russie ancienne. Enseignant enthousiaste et collègue généreux, Victor Živov est regretté par tous ceux qui ont eu la chance de le connaître. (NdlR)

\section{ДВА ЭТАПА ДИСЦИПЛИНАРНОЙ РЕВОЛЮЦИИ В РОССИИ XVII И XVIII СТОЛЕТИЯ}

\section{Религиозное дисциплинирование как модернизационный процесс}

Концепция дисциплинарной революции как одного из основных исторических процессов раннего Нового времени, лежащих в основе формирования универсального по своим функциям (абсолютистского) государства и модерного общества, в наиболее четком виде была изложена в книге Филиппа Горского ${ }^{1}$. Горски полагает, что в этих процессах важнейшую роль играла конфессиональная политика, которая в период Реформации и Контрреформации оказывала доминирующее влияние на социально-политические

1. Ph. Gorski, The Disciplinary Revolution: Calvinism and the Rise of the State in Early Modern Europe, Chicago - London: Univ. of Chicago Press, 2003. 
процессы. Он основывается на парадигме конфессионализации, в рамках которой религиозные цели церковных институций находили понимание и поддержку у светских властей, заинтересованных в этом сотрудничестве как в важнейшем средстве контроля над населением. Государство, реорганизованное на приницпах конфессионализации, обретало благодаря церковным институтам административные возможности дисциплинирования населения ${ }^{2}$; эти возможности использовались прежде всего в призрении бедных, реформировании образования и более жесткой регламентации сексуальных и брачных отношений.

Горски соединяет в своем подходе концептуальные инновации Макса Вебера, Норберта Элиаса и Мишеля Фуко. Он пишет о связи религии с дисциплиной, дисциплины с государством и инициатив снизу и сверху как источников социальных процессов. Как формулирует Горски,

state capacity is a function, not only of administrative rationalization, but of the strength of the social infrastructure and the rationality of sociopolitical ethics. The more extensive the infrastructure and the more rational the ethic, the stronger the state will be $\mathrm{b}^{3}$.

Горски в своей типологии не упоминает Россию, кроме одного сравнения Петра Великого с Фридрихом Великим и указания на то, что при всей централизации петровская бюрократия была коррумпирована и неэффективна, тогда как бюрократия Фридриха отличалась моральным достоинством и эффективностью ${ }^{4}$. Не говорит он и о православии, рассуждая лишь о католицизме, лютеранстве и кальвинизме. Тем не менее и в России были попытки осуществить дисциплинарную революцию, которая, как и в других европейских странах, оказывалась важной частью государственного строительства.

\section{Первый этап}

Попытки реформирования религиозной жизни русского населения начинаются после Смутного времени: катастрофа начала XVII в. диктовала в восприятии современников необходимость «исправы», «восстановления» благочестия 5 . Средневековая русская сотериологическая концепция предполагала, что спасение должно было приходить само собой, вне опреде-

2. A. Schindling, "Kirchenspaltung, Konfessionsbildung und Konfessionalisierung als ein Grundproblem der deutschen und westeuropäischen Geschichte im 16. Jahrhundert", in Конфессионализация в западной и восточной Европе в раннее Новое время / Konfessionalisierung in West- und Osteuropa in der frühen Neuzeit, Доклады руссконемецкой научной конференции 14-16 ноября 2000 г., СПб.: Алетейя, 2004, p. 33-43.

3. Gorski, The Disciplinary Revolution, p. 37-38.

4. Там же, р. 175, прмеч. 30.

5. Прот. Г. Флоровский, Пути русского богословия, Изд. 4-е, P.: YMCA-Press, 1988. 
ленной связи с человеческими усилиями, с нравственным поведением или дисциплиной христианской общины. Спасение состояло в постепенном преображении этого мира в Царство Небесное и осуществлялось не через нравственное совершенствование, но как распространение литургического космоса во внешний для него мир. В литургии Небеса нисходят на землю и преображают ее. Распространение этого обоженного состояния мира, т. е. его спасение не требует человеческих усилий, но осуществляется самодеятельно, так что община верующих должна лишь поддерживать богослужебное действие в его преемственности и чистоте. Все прочее, как, в частности, аскетические подвиги, богословское познание, институализованное покаяние или дела милосердия, было факультативным, необходимым в основном лишь для тех, кто превратил спасение в свое каждодневное дело, т. е. для монахов и монахинь.

В Смутное время на Россию вместо этого самодеятельного спасения обрушились немыслимые несчастия. Отсюда следовало, что русские плохо молились, плохо оберегали православное благочестие, плохо служили Богу и получили воздаяние за свою неправедность. Это создавало условия для религиозной и нравственной реформы, для формирования нового религиозного движения, целью которого было бы исправление благочестия и нравственное преобразование общества. Насколько распространено было такое восприятие истории, судить сложно, но у определенной группы населения оно несомненно присутствовало, и именно такие, часто небольшие группы оказываются начинателями реформационных процессов. Интересующее нас восприятие очевидным образом присутствовало у девяти нижегородских священников, написавших в 1636 г. челобитную патриарху Иоасафу. Священнослужители просят патриарха издать указ, исправляющий недостатки русской церковной жизни. Сама челобитная наполнена весьма красноречивым описанием этих недостатков, и исправление их представлено как необходимое условие для отвращения тех бедствий, которые уже обрушились на Русь и неминуемо обрушатся опять «грех ради наших»:

Во истину государь образ Божїи и сновство обругахом и пременихомся ко дщерем сатанинским - ко злым его прелестемъ, и не ощущаемъ Ноева человека, сїиреч званїя Христова, творим злая, прїидут ли на ны благая? Чего не пострадахом? не пленена ли земля наша? не взяти ли гради наши? не падоша ли без оружїя? не помроша ли скоти и не оскудеша ли нивы? Сїя государь вся ныне содеяся пред очима нашима в наше наказанїе, и никако ж воспомянухомся. ${ }^{6}$

6. Н.В. Рождественский, К истории борьбы с иерковными беспорядками, отголосками язычества и пороками в русском быту XVII в. (Челобитная нижегородских священников 1636 года в связи с первоначальной деятельностью Ивана Неронова). - Чтения в Имп. Обществе истории и древностей российских, 1902, кн.2, Смесь, 1-31, с. 27. 
Сходные сетования и опасения можно найти и в челобитной выборного курских детей боярских Г.В. Малышева немногим более позднего времени ${ }^{7}$ что как раз и указывает на связь реформационного движения с памятью о разорении Смутного времени.

Именно в этих условиях обнаруживаются первые начатки дисциплинарной революции. Они в основном связаны с деятельностью церковных активистов, прежде всего так называемых ревнителей благочестия ${ }^{8}$. Одним из наиболее видных членов этого кружка был Иоанн Неронов, участвовавший в написании нижегородской челобитной 1636 г. и бывший, возможно, ее вдохновителем. Как и в западноевропейских реформационных движениях, цели преобразований соответствовали сотериологическим концепциям реформируемого общества. Особенности русской реформации состояли не в характере этого соответствия, а в характере сотериологических концепций. Первое, что волнует реформаторов, - это «правильные» обряды, в частности, правильное течение литургической жизни: неблагочестие именно в этой сфере отвращает спасение и ведет к погибели.

Первое, на что жалуются нижегородские священники, это многогласие в церковной службе, т.е. одновременное чтение и пение различных частей службы разными священнодействующими церковнослужителями и хором. Эта тема находит продолжение во всем последующем реформационном движении . Начав с многогласия, нижегородские попы перечисляют далее и другие недостатки в богослужебной практике, которые и представляют для них наиболее опасные преступления против христианского благочестия:

Въ церквах государь зело поскору пенїе, не по правилом святых отецъ ни наказанїю вас государей, говорять голосов в пять и в шесть и боле, со всяким небрежением, поскору. Ексапсалмы государь такоже говорят с небрежениемъ не во един ж голос и в ту ж пору и псалтыр и каноны говорят, и в ту ж пору и поклоны творят невозбранно. А сщенницы государь о том мир не наказываютъ, чтоб стояли въ церькви со страхом и благочинно, по правилом святых апост[о]лъ и святых отецъ и вас государей $<\ldots>$ a се государь литоргїи Божїи служат без часов. толко отпустом начинают. ${ }^{10}$

\section{7. Там же, с. 5.}

8. См.: С. Зеньковский, Русское старообрядчество: Духовные движения семнадиатого века, München: Wilhelm Fink Verlag, 1970 [Forum Slavicum, Bd.21]; P. Pascal, Avvakum et les débuts du Raskol : La crise religieuse au XVIt siècle en Russie, P.: Librairie ancienne Honoré Champion, 1938. Полезный обзор литературы о ревнителях благочестия можно найти в монографии: W. Heller, Die Moskauer "Eiferer für die Frömmigkeit” zwischen Staat und Kirche, Wiesbaden: Harrassowitz, 1988 [Veröffentlichungen des Osteuropa-Institutes München, 56 Bd.]. Концептуальные построения самого автора этой книги не кажутся вполне убедительными.

9. О борьбе с многогласием см.: Н.Ф. Каптерев, Патриарх Никон и иарь Алексей Михайлович, Сергиев Посад, 1909-1912 [репринт: М.: Изд-во Спасо-Преображенского Валаамского монастыря, 1996], I, с. 81-105; Зеньковский, Русское старообрядчество, c. $112-123$.

10. Рождественский, К истории борьбы с иерковными беспорядками, с. 19-21. 
Основной жалобой оказывается, таким образом, указание на неисправности в богослужении, прежде всего его сокращения, «лености ради», нарушающие установленный святыми отцами порядок. При этом ленивые священники и их прихожане не хотят исправляться и, отделываясь от упреков реформаторов, их настояния выдают за нововведения и требуют указа из Москвы. Многогласием и опущением часов не ограничиваются претензии реформаторов. Они возражают и против перенесения вечерни и утрени, приспосабливающего богослужение к удобному для прихожан времени, но приводящего к тому, что «поют пооутру: пришедшу солнцу на запад, а солнце еще въсходит» ${ }^{11}$. Отсюда, на взгляд нижегородских попов, происходит «людем смута и о вере поврежденїе» ${ }^{12}$. Далее идут сетования на скверное поведение прихожан во время богослужения, на то, что они не слушают «со вниманїем» службу, но шумят и ходят по церкви, а «иногда дерутся в церквах и бранятся» ${ }^{13}$.

Затем трактуется тема «народного язычества». Праздники церковные должны быть отмечены особым благоговением христиан.

В насъ ж государь сїя пренебрегома и, яко что неистинно дело, презираемо, и вся противно творим и ругателно праздником Господьскимъ: вместо радости духовныя, и возделанїе творят радости бесовской, многими государь еллинскими и бесовскими играми дни сїя проподаютъ. От Рожества Христова и до Богоявленїя делают государь по домох игрища и $<. .>$ на лица своя полагають личины косматыя и зверовидныя и одежду таковую ж, а созади себе оутверждають хвосты, яко видимыя беси, и срамная оудеся в лицех носяще и всякое бесовско козлогласующе и об(ъ) являюще срамныя оуды <..> А в навечери государь Рождества Христова и Богоявленїя такожде ходятъ по оулицам толпами и поют бесовскїя песни и кличют коледы, творят затеи бесовскїя ${ }^{14}$.

Развивая эту линию, негодующие священнослужители говорят о скоморохах, скоморошеских играх, медведчиках «с медведи и плясовыми псицами», о пьяницах и корчемниках, об употреблении нечистой еды, качании на качелях и различных местных обрядах «языческого» происхождения. Во всех этих случаях речь идет не столько о нравственном усовершенствовании общества, сколько об исправлении ритуальных практик: с одной стороны, это практики церковно-богослужебные, из которых должны быть устранены различные послабления и нестроения, с другой - это народная внецерковная обрядовость, которая осмысляется реформаторами как антихристианская и которая, на их взгляд, должна быть полностью искоренена. Именно на этих (обрядовых) практиках ставится акцент, именно здесь реформа должна открыть
11. Там же, 21.
12. Там же, 22.
13. Там же, 23.
14. Там же, 24-26. 
путь к спасению, тогда как другие аспекты христианской жизни, хотя и могут присутствовать, но остаются на втором плане.

В ответ на нижегородскую челобитную патриарх Иоасаф выпустил в 1636 г. меморандум, поддерживающий эти требования, но излагающий их в значительно смягченном виде ${ }^{15}$. Дисциплинирующая эффективность этого меморандума была, видимо, минимальной, однако он превращает частные сетования в религиозную политику и может рассматриваться как веха в истории русской дисциплинарной революции.

Конечно, деятельность ревнителей благочестия (боголюбцев) и их предшественников обладала и другими аспектами, в большей степени напоминающими западноевропейские дисциплинирующие реформы (хотя борьба с «народными» суевериями и «бесовскими игрищами» была отнюдь не чужда Реформации). В ней присутствовала проповедь нравственного обновления и стремление создать сообщество сознательных христиан, для которых благочестие было бы внутренним императивом ${ }^{16}$. Весьма показательно, что в борьбе реформаторов за единогласие фигурировал нетрадиционный для православной духовности аргумент назидательного значения богослужения; можно напомнить, что в традиционном благочестии богослужение было обращено к Богу, а не к пастве, и поэтому существенны были его чистота и полнота, а не понятность и назидательность (что и обусловливало многогласие). Теперь же боголюбцы задаются вопросом: «кая же польза получити предстоящим в церкви людем во время божественнаго пения, егда в гласа два или три и множае вдруг говорят, - никако ничесого, точию шум всуе, и без пользы, и пагуба с великим грехом» ${ }^{17}$. Это новое понимание, разрушительное для традиционной сотериологии. Спасение ставится в зависимость от индивидуального благочестия, и духовные вожди хотят апроприировать время индивида, чтобы направить общество на путь спасения ${ }^{18}$.

15. Там же, 2-5.

16. А.С. Лавров привлек внимание и к такому обычно игнорируемому аспекту деятельности ревнителей благочестия, как миссионерство, т.е. обращение (порою насильственное) неправославных в православие, А. Lavrov, «Ein vergessener "Eiferer der Frömmigkeit" und Missionar: Daniil von Temnikov» in E. Andor and I.G. Tóth, eds., Frontiers of Faith: Religious Exchange and the Constitution of Religious Identities 14001750, Budapest: Central European University, 2001, с. 375-380. С одной стороны, эта деятельность внутренне связана с борьбой против народных «бесовских игрищ», которые рассматриваются как свидетельства иноверия («язычества»). С другой стороны, дисциплинарные революции нацелены на религиозную консолидацию общества и предполагают его конфессионализацию.

17. Каптерев, Патриарх Никон и царь Алексей Михайлович, I, с. 88.

18. Ср.: В.М. Живов, «Время и его собственник в России раннего нового времени (XVIIXVIII века)», in В.М. Живов, ред., Очерки исторической семантики русского языка раннего Нового времени, М.: Языки славянских культур, 2009, с. 49-50). Индивиды, включая традиционное духовенство, сопротивляются, поскольку богослужение оказывается бесконечно долгим. Церковный собор 1649 г. под председательством патриарха Иосифа, противника реформаторской деятельности боголюбцев, высказался против единогласия, указывая, что «[в] Москве учинила[сь] молва великая і всяких чинов православни[е] людие от церквей Божіх учали отлуча[тися] за долгим и безвременным пением» (Чтения 
В деятельности боголюбцев присутствовала и проповедь, что в русских условиях было значительной инновацией, поскольку до XVII в. устная проповедь священниками не практиковалась. Как пишет, цитируя Житие Неронова, С.А. Зеньковский в рассказе о его деятельности в Нижнем Новгороде ${ }^{19}$,

деятельность Неронова по объяснению смысла учения Христа была чем-то совсем необычным и даже революционным для церковных нравов Руси того века. $<\ldots>$ «Иоанн же, почитавше им божественные книги с рассуждением и толковаше всяку речь ясно, и зело просто, слушателям простым. Поучая народ, кланяшеся на обе стороны до земли, со слезами моля дабы вси, слышаще, попечение имели всеми образы о спасении своем»... Но этой умилительной проповедью спасения душ Неронов не ограничивался, но еще просил прихожан и посетителей, «чтобы они и дальше несли слово Христово» и проповедовали его «в домах своих» и убеждали бы всех своих близких и самих себя найти путь ко спасению. Этот опыт сделать и мирян носителями слова Божия уже был совсем необычен не только в русской, но даже и в Западной практике средневековья и скорее приближался к типу протестантской проповеди. Церковь не была единственным местом призывов Иоанна ко спасению, так как после церкви он обычно шел на улицы и площади города, «неся с собой книгу великого светильника Иоанна Златоуста, именуемую “Маргарит”, и «возвещал всем путь спасения» ${ }^{20}$.

Когда в 1645 г. на престол вступает молодой Алексей Михайлович, он начинает проводить в жизнь реформистскую программу ревнителей благочестия. Накануне Великого поста 1647 г. царь побуждает патриарха Иосифа выпустить окружное послание, побуждающее духовенство молиться благочестиво и жить в чистоте и трезвости. За этим следует указ, требующий, чтобы по воскресениям народ ходил в церковь, а корчмы и лавки были закрыты (это вполне напоминает деятельность пуритан в Англии этого же периода). Эти действия отнюдь не встречали всеобщего одобрения. Традиционно настроенное духовенство, включая патриарха Иосифа, отнеслось к ним без

в Обществе истории и древностей российских при Московском университете, ЧОИДР, 1894, кн.4, III. Исслед., с. 36-37).

19. Зеньковский, Русское старообрядчество, с. 78-79.

20. Основным источником сведений о деятельности Неронова остается его Житие (см.: Материаль, I, Материаль для истории раскола за первое время его существования, под ред. Н.И. Субботина, Т. I-IX. М., 1875-1890). Ряд важных свидетельств, обнаруженных в последне время, см. в: Н.Ф. Филатов, «Иван Неронов. Пора становления», Tруды Отдела древнерусской литературы, Т. 48, 1993, 319-322; Г. Михельс, «О деятельности Ивана Неронова в первые годы никоновской реформы», Русское общество и литература позднего феодализма, Новоибирск, 1996, 23-36; Т.А. Опарина, «Грамота Монастырского приказа 1656 г. о “сыске и поимке” Ивана Неронова», Старообрядчество в России (XVII-XX века), вып. 3, М., 2004, 75-80; А.С. Лавров, «Письмо и челобитная Ивана Неронова», Древняя Русь. Вопросы медиевистики, 2009, № 1 (35), 101-106. Неронов может рассматриваться как центральная фигура для всего боголюбческого движения, поскольку в его случае реформаторство остается актуальным и тогда, когда он стоит на стороне старообрядцев, и тогда, когда он примиряется с Никоном. Он соединяет в себе два враждующих лагеря как две ипостаси одного реформационного движения и свидетельствует о реформаторской природе раннего старообрядчества. 
энтузиазма. С их точки зрения этот проект нравственного возрождения накладывал слишком тяжелое бремя как на них самих, так и на их паству.

Алексей Михайлович и ревнители благочестия откладывали более решительные шаги в ожидании кончины патриарха Иосифа, но при этом продолжали свои усилия. 5 декабря 1648 г. царь в обход патриарха выпустил указ, который должен был читаться по всем церквям по воскресениям и праздникам. Этот указ требовал от подданных царя, чтобы они воздерживались от возмущающих благочестие и бесовских деяний. Указ запрещал скоморошеские зрелища, показ дрессированных медведей и дрессированных танцующих собак (все то же, что и в нижегородской челобитной) и пение бесовских песен; православные призывались не посещать ворожей и зелейников. Поскольку время приближалось к святкам, в указе специально говорилось о том, что запрещается носить маски или гадать на луну, возбранялись неблагочестивые процессии и банные бесчинства. Скоморошеские музыкальные инструменты подлежали конфискации и сожжению. Нарушителей предписывалось пороть, а при неоднократном повторении запрещенных действий высылать из городов ${ }^{21}$. Это была явно боголюбческая программа, отличие было в том, что теперь эта программа шла от верховной власти и отделаться от этих требований становилось труднее, хотя о последовательном исполнении их речь тоже, конечно, не шла, и у царя явно не доставало средств принуждения, чтобы провести меры, не пользовавшиеся популярностью не только у большой части населения, но и у служилой элиты (в частности, бояр и воевод) и духовенства. Указ в определенной степени оставался декларацией, но и декларации имели важное историко-культурное значение.

С этого времени дисциплинарные усилия светской и духовной власти идут параллельно ${ }^{22}$. Следует предположить, что эти параллельные усилия регламентировать религиозную жизнь означали не только сотрудничество двух властей, духовной и светской, но и их скрытую конкуренцию (особенно заметную в Уложении 1649 г. ${ }^{23}$ ): тот, кто издает приказы, обладает верховной

21. Ph. Longworth, Alexis, Tsar of All the Russias London: Secker \& Warburg, 1984, p. 54-55.

22. Ср., например, дальнейшие регламентационные действия царя в грамоте свияжскому воеводе: G.B. Michels, At War with the Church: Religious Dissent in Seventeenth-Century Russia, Stanford: Stanford Univ. Press, 1999, p. 189, 293; текст грамоты: ПСЗ, Полное собрание законов Российской империи [Собрание 1-е], Т.1-45, СПб., 1830, I, № 47, с. 246).

23. Здесь можно упомянуть, что в первой главе Соборного Уложения 1649 года говорится «о богохульниках и о церковных мятежниках» (Соборное уложение 1649 года, Текст, комментарии, под. ред. А.Г. Манькова, Л.: «Наука», 1987, с. 19). Место Уложения 1649 г. в церковной политике Алексея Михайловича неоднозначно. В согласии с ним учреждается Монастырский приказ, сокращавший компетенцию церковной администрации в пользу светской, но вместе с тем предписываются такие нормы православного благочестия, как: «И православным христианом подобает в церкви божии стояти и молитися со страхом, а не земная мыслити» (там же). Вся эта глава была инновацией царских законодателей. Хотя отдельные статьи этой главы могут возводится к различным византийским и западным источникам (см. об этом: там же, 141-145; см. также: А.В. Попов, Суд $u$ наказания за преступления против веры и нравственности по русскому праву, Казань, 1904, с. 150-155), она в целом была плодом оригинального юридического творчества и воплощала политику религиозного дисциплинирования. 
властью в области, к которой приказы относятся. Собственно, реформы патриарха Никона (или, вернее, реформы царя Алексея Михайловича, которые проводил и за которые нес ответственность Никон) укладывались в это же русло: они состояли в реформировании и унификации обрядовых практик и в этом отошении были дисциплинирующими преобразованиями. От дисциплинирования 1640-х годов они отличались не существом, а ориентацией; место некоей неопределенной, но освященной святоотеческой традицией модели благочестия занимает теперь образец современных греков, нередко несогласный с русской традицией и для русских подозрительный.

Определенной вехой в дисциплинарной революции был Большой Московский Собор 1666-1667 гг. Этот собор был своего рода компромиссом между притязаниями духовной и светской власти: епископы признали верховную власть царя и осудили «папистские» идеи Никона, но одновременно иерархия вернула себе управление церковными делами, включая и религиозное дисциплинирование ${ }^{24}$. Реализация этого компромисса зависела от меняющихся исторических обстоятельств: сначала преимущество было у царя, но после избрания в 1672 г. патриарха Иоакима и в особенности после смерти Алексея Михайловича в 1676 г. чаша весов склонилась на другую сторону ${ }^{25}$. Начиная с 1670-х годов контроль над благочестием населения оказывается практически целиком в руках духовенства.

В Деяниях Собора мы находим обширный перечень дисциплинирующих установлений. В него входят и элементарные требования благопристойного поведения верующих во время богослужения, и - в одном ряду с ними осуждение традиционных «харизматических» нарушений церковной благопристойности. Так, если

нищие во время пения учнутъ по церкви бродить и темъ милостини давати не велеть, а велети их смиряти священиком за безъчинство. Тако же бы велети имати и власы растящихъ, и ризы черные носящихъ и босых ходящихъ, иже мнятся благоговеини быти, не суть же такови ${ }^{26}$ (далее идет ссылка на постановления VI Вселенского собора, направленные против странствуюшщих монахов) $)^{27}$.

24. Каптерев, Патриарх Никон и изарь Алексей Михайлович, II, с. 223, 250.

25. Cp.: P. Bushkovitch, Religion and Society in Russia: The Sixteenth and Seventeenth Centuries, New York - Oxford: Oxford University Press, 1992, p. 72.

26. Деяния Московских Соборов 1666 и 1667 годов (под ред. Н. Субботина), изд. 2-е Братства Св. Петра Митрополита, вновь проверенное по подлинной рукописи. М.: Синодальная типография, 1893. Reprint: Westmead: Gregg International Publishers Limited, 1969, л. 45; Материаль для истории раскола, II, с. 137-138.

27. Регламентация монашеской жизни занимает вообще важное место в деяниях собора, в частности, столь характерный для дисциплинарных практик запрет странничества (Деяния 1969, л.25-27об.; Материалы, II, 256-262). Эта традиционная борьба институциональной церкви с харизматической религиозностью (см. о Византии в этом отношении: G. Dagron, « Les Moines et la Ville. Le Monachisme à Constantinople jusqu'au concile de Chalcédoine (451)», Travaux et Mémoires, 4,1970, p. 229-276) делается особенно актуальной в России второй половины XVII в. как в виду раскола (который никем не 
Особое внимание уделяет Большой Московский собор аскетам-харизматикам и юродивым, которые для институциональной церкви могли быть конкурирующим источником святости и благодати. В Деяниях говорится:

Суть некоторїи лицемернїи и прелестники, иже живуть посреди градовъ, и селъ, во образъ отшелника, и затворника волосати, и въ монашеской свитце. Инииже и въ железахъ сковани. Такожде и наги и боси ходятъ по градам и селамъ въ мїре, тщеславїя ради, да воспрїимутъ славу от народа, и да почитаютъ ихъ во святыхъ, ко прелести простымъ и невеждамъ. Повелеваемъ убо, отныне да не имете отнюдъ таковым веру, зане познавается, яко не по бозе, и не въ правду, и ниже здравымъ оумомъ сїя творятъ. ${ }^{28}$

В аналогичных терминах дискредитируются и юродивые, которые в русской религиозной жизни XVI-XVII вв. выступают едва ли не как главные носители благодати ${ }^{29}$. Одним из аспектов дисциплинарной революции была институализации спасения. Распределителем спасения должна была быть официальная церковь, которая - в лице иерархии и правильно поставленного духовенства и руководствовала верующих на пути в Царствие Небесное: несанкционированные агенты были не только лишними; их деятельность была вредоносной. В орбиту официального надзора, переоценки и порою запрета вовлекаются местные святыни и священные источники, чудотворные иконы и предположительно поддельные мощи, - все то, что создавало фактуру религиозной жизни православной общины и было основанием для местной религиозной идентичности.

Георг Михельс предлагает считать, что старообрядческое движение было в значительной степени реакцией на дисциплинирование и подавление местных традиций центральной властью, тогда как исправление книг и обрядовые инновации патриарха Никона были лишь вторичным обоснованием более широкого протеста. Он утверждает, что

it appears that the Russian Schism resulted from official church policies. By suddenly and drastically intruding into age-long local and personal autonomies, the church generated popular opposition to its reforms. Rejection of the Nikonian reforms was therefore largely a response by communities as well as individuals to the church's insistence on controlling the religious affairs of Muscovy's hinterlands. ${ }^{30}$

контролируемое монашество могло весьма успешно поддерживать и распространять), так и в силу общего стремления к религиозному дисциплинированию.

28. Деяния Московских Соборов 1666 и 1667 годов, 1969, л. 27об.-28; Материаль для истории раскола, II, с. 262-263.

29. Деяния Московских Соборов 1666 и 1667 годов, 1969, л. 28-28об; Материаль для истории раскола, II, с. 263; ср.: С.А. Иванов, Блаженные похабы: Культурная история юродства, М.: Языки славянских культур, 2005, с. 265-316.

30. Michels, At War with the Church, p. 220. 
Такая точка зрения может быть принята лишь частично ${ }^{31}$, хотя она обладает тем достоинством, что трактует в качестве элементов единого целого различные процессы социального и религиозного дисциплинирования, разнородные негативные реакции на эти процессы и последующую конфессионализацию старообрядчества.

Для процесса институализации спасения как части дисиплинарной политики особенно важно было устрожение покаянной дисциплины. Большой Московский собор настаивал на регулярной исповеди («в четыре святые посты») и причастии ${ }^{32}$. Те, кто уклонялся от долга ежегодной исповеди и причастия без особых причин, должны были быть лишены христианского погребения. Уже в это время регулярная исповедь и причастие стали употребляться как инструменты обнаружения и преследования религиозных диссидентов, прежде всего старообрядцев. Архиереи через своих подчиненных контролировали соблюдение введенных Собором правил ${ }^{33}$. Важно отметить, что списки исповедников появились уже в 1680-х и 1690-х годах, и эта инициатива принадлежала епископату ${ }^{34}$. Патриарх Адриан в Инструкции поповским старостам предпринял попытку сделать эту практику обязательной ${ }^{35}$.

Начатая боголюбцами борьба с народными обычаями, верованиями и магическими практиками также находит продолжение во второй половине XVII в. Показательно, что именно в это время появляется обобщенное понятие суеверия в соответствии с лат. supertitio. Эта языковая инновация непосрественно связана с политикой религиозного дисциплинирования: для

31. Автор не уделяет достаточного внимания основной проблеме раскола: в результате чего движение ревнителей благочестия, довольно непопулярное и встречавшее враждебную реакцию со стороны большинства населения, превратилось в старообрядчество, выражавшее чаяния больших групп населения? На мой взгляд, главным моментом в этой трансформации была апроприация программы ревнителей благочестия государством или, точнее сказать, царем. Эта апроприация сопровождалась сакрализацией царской власти (и была органически с нею связана); царская власть была реконцептуализирована как вездесущая и неограниченная в ее правах на вмешательство в жизнь общества, в том числе и в его религиозную жизнь. Это стало причиной широкого протеста.

32. Деяния Московских Соборов 1666 и 1667 годов, 1969, л. 42об.; Материаль для истории раскола, II, с. 132-133.

33. Об инструкции новгородского митрополита Корнилия 1682 г., см. Michels, At War with the Church, p. 116.

34. Там же, 293, прим. 6.

35. ПСЗ, III, № 1612, с. 413-425, 26 декабря 1697. Списки исповедников отнюдь не были особым изобретением русских архиереев. Та же практика была характерна для католической Европы в период Контрреформации. "After the Council of Trent, diocesan and provincial synods began to order pastors to keep records of parish events such as births, deaths, and baptisms, and of those who fulfilled their Easter obligations" (W.D. Myers, "Poor, Sinning Folk": Confession and Conscience in Counter-Reformation Germany, Ithaca London: Cornell Univ. Press, 1996, 116); см. также о Articuli Reformationis, изданных в 1590 Урбаном фон Тренчем, епископом Пассау (ibid, 121). Правдоподобно, что у русских епископов имелась какая-то информация об этой католической практике и мы здесь имем дело с одним из элементов католического влияния. Конечно, документы этого типа были необходимы для контроля, осуществляемого вышестоящими институтами, и поэтому обзаведение ими могло происходить независимо от сходных мер в других странах. 
того чтобы истреблять суеверия, неоходимо было иметь понятийную основу этой деятельности, которая позволяла бы исчислить разнообразные виды суеверий, чтобы ни одного из них не оставить без внимания.

Первое употребление этого слова находится в «Слове о суеверии и суечестии» Симеона Полоцкого ${ }^{36}$. Симеон пространно рассуждает о разновидностях суеверий, о их внутренней взаимосвязи и об их губительной природе. Он перечисляет подрубрики и приводит многочисленные примеры. Хотя у него много местного материала, вполне очевидно, что классификационную схему он берет из латинского источника, опосредованного восходящего к Summa theologiae Фомы Аквинского ${ }^{37}$.

Симеон начинает с указания на многообразие суеверий и затем перечисляет, впрочем, без свойственной схоластике четкости, о суеверии идолопоклонства, суеверии гаданий и суеверии магических ритуалов. Симеон не проходит мимо и superstitiones indebiti cultus veri Dei, первого разряда в классификации Фомы. Симеон, несомненно знакомый с католическими теориями, оказывается здесь новатором, поскольку раньше данные явления не были предметом обличения, хотя, надо заметить, об этом виде суеверия говорится отнюдь не на первом месте и как бы мимоходом. Симеон пишет:

Суеверїя видъ есть, чюдесемъ неправеднымъ, или небывшымъ, въскоре и кроме свїдетелствъ веру яти, проповедати же словомъ, или писанїемъ: Нечестїе же мощи иныя, въместо святыхъ: или вещь ину, въместо мощей святыхъ подълагати ${ }^{38}$,

однако вслед за этим без всякого перехода говорится о встрече с волком, зайцем или иноком как дурных предзнаменованиях, что у Фомы относится, конечно, к superstitiones divinationum, так что Симеон оказывается не очень тверд в классификации. Как бы то ни было, Симеон не только создает слово суеверие, но и утверждает в русской дискурсивной практике само понятие о суеверии, руководствуясь при этом западными (без сомнения, католическими) образцами ${ }^{39}$.

36. [Симеон Полоцкий], Вечеря душевная, М.: Верхняя типография, 1683 л. 32-40, 2-й пагинации [Приложение слов на различныя нужды]; ср.: Е. Смилянская, «“Суеверия” и народная религиозность в России Века Просвещения», Canadian American Slavic Studies, 38 (1-2), 2004, c. 121-154.

37. Фома анализирует проблему суеверий в вопросах 92-96 второй части второй книги Суммы. Понятие superstitio подразделяется на четыре разряда: (1) неправильное почитание истинного Бога; (2) суеверие идолопоклонства; (3) суеверие гаданий; (4) суеверие обычаев (разбирая понятие суеверия, он пишет «primo, de superstitione indebiti cultus veri Dei; secundo, de superstitione idololatriae; tertio, de superstitione divinationum; quarto, de superstitione observationum» (Quaestio 93, Prooemium) (Фома Аквинский, $\mathrm{XL}, 2-85)$.

38. [Симеон Полоцкий], Вечеря душевная, л. 33об.-34.

39. Стоит отметить, что в этот же период (последняя треть XVII в.) из польского заимствуется слово забобоны, также означающее 'superstitio'. Такой повышенный спрос на слова с одним значением не может быть случайным. Мы имеем дело с заимствованием 
Таким образом, первый этап дисциплинарной революции в России определяется ведущей ролью институциональной церкви, стремящейся взять под свой контроль религиозные практики православного населения. В соответствии с русскими сотериологическими концепциями религиозная реформа выдвигает на первый план обрядовые преобразования - как регуляризацию богослужения, так и искоренение народных магических ритуалов. В этих же рамках подавляется внеинституциональная харизматическая религиозность (в частности, юродство) и локальные культы, нарушающие монополию институциональной церкви на обеспечение спасения. Возрастает роль покаянной дисциплины и проводится целенаправленная борьба с суевериями, обретающая теоретический фундамент.

\section{Второй этап}

Инструкция патриарха Адриана поповским старостам 1697 г. была последней попыткой церковной иерархии как независимого института расправиться с девиантными явлениями народной духовности и обеспечить поддержку институционализованным и контролируемым формам религиозной жизни. В 1700 г. патриарх Адриан умер, и для церкви начался период разрухи и потрясений. Монастырский приказ получил контроль над церковным имуществом и доходами; церковное управление было в полном расстройстве: нового патриарха не избирали, а многие епископские кафедры пустовали годами. Петр Великий даже не делал вид, что он благочестивый православный царь; он брил бороды, развелся с женой и открыто жил с любовницей, предавался кощунственным развлечениям и разными способами старался дискредитировать патриаршее достоинство. Вплоть до середины 1710-х годов церковная политика Петра была по сути деструктивной ${ }^{40}$. Никто в этих условиях не мог всерьез заботится о религиозном дисциплинировании, в дисциплинарной революции случился перерыв.

В середине 1710-х годов религиозная политика Петра I претерпевает существенные изменения. Они, можно полагать, связаны с тем, что Петр стремится не только сокрушить старое, но и создать такие социальные навыки и государственные институты, которые обеспечили бы будущее тем преобразованиям, которые он произвел ${ }^{41}$. Петр мечтает о построении «регулярного» государства. Сама идея требовала социального дисциплинирования, в том числе и в сфере религиозной. Поэтому политика религиозного дисциплинирования окончательно апроприируется государством. Процесс этот имеет не только

обобщающего понятия, необходимость в котором возникает в рамках общего процесса религиозного дисциплинирования населения.

40. Ср.: В.М. Живов, Из иерковной истории времен Петра Великого: Исследования и материальь, М.: Новое литературное обозрение, 2004, с. 34-48.

41. См. подробнее: Живов, Из церковной истории времен Петра Великого, с. 54-56. 
значительно более радикальный характер, чем при Алексее Михайловиче, но и отличия по существу: Алексей Михайлович ставил перед собой задачи религиозной реформы и ради этого подчинял себе церковную политику; Петр ставил себе задачи социально-политического преобразования, для которого традиционная религиозность была помехой, в силу чего он и стремится с нею расправиться. Петр, в отличие от своего отца, не религиозный реформатор, а ниспровергатель «клерикального» порядка.

Для государства, которое замышлял Петр, было необходимо всеобщее служение; для того чтобы внушить населению этот идеал, Петру нужно было представить служение государству как высшую добродетель. В силу этого служба претендовала на то, чтобы стать не только основой социального успеха, но и главным инструментом христианского спасения. В текстах петровского времени неоднократно утверждалось, что, служа отечеству, спастись можно скорее, чем в молитвенном затворничестве. Эта секуляризованная сотериология подробно аргументируется Феофаном Прокоповичем в Слове в день святого благоверного князя Александра Невского 1718 г. Феофан, с отвращением отвергая мнение некоторых, которые «к монахом глаголют: вы едини блажени, вам единым спастися», утверждает, что спасение предназначено для всех. Это спасение каждого в предписанной ему его состоянием (чином) деятельности (на благо общества, т.е. государства) противопоставляется зловредным клерикальным вымыслам ${ }^{42}$ :

И каковое неистовство в сердца многих вселилося! аки бы другий желает как спастися, а что по званию своему должен, о том ниже помышляя, но и многажды еще званию своему противное творя, ищет пути спасеннаго у сынов погибельных, и вопрошает: как спастися? у лицемеров, мнимых святцев, и разве для того безгрешных, яко о грехах своих не помышляют: что же они? видения сказуют, аки бы шпионами к Богу ходили, притворныя повести, то есть бабия басни бают, заповеди бездельныя, хранения суеверная кладут, и так безстудно лгут, яко стыдно бы воистинну и просто человеком, не точию честным нарещися тому, кто бы так безумным расказщикам верил: но обаче мнози веруют, увы окаянства! О слепии спасения искатели! которых такое буесловие услаждает. Сей ли путь спасения? яко помрачен забобонами не знаеш, что ты должен еси Богу, Государю, отечеству, всякому собственно ближнему, словом рещи, что должен званию твоему. А не ведати сего и не творити, не есть ити спасенным путем; ибо не есть то ходити по воли Божией, но паче воли Божией противитися» (Феофан Прокопович, II, 16).

42. Феофан приводит и наглядный пример пагубного клерикализма: «А от сего является, коликое неистовство тех, котории мнятся угождати Богу, когда оставя дело свое, иное, чего не должни, делают: судия, на пример, когда суда его ждут обидимии, он в церкви на пении: да доброе дело: но аще само собою и доброе, обаче понеже не во время, и с презрением воли Божия, како доброе, како богоугодные быти может? Ищут суда обидимии братия, и не обретают $<\ldots>$ а для чего? судия богомольствует. О аще кая ина есть, яко сия молитва в грех! Сие же разсуждение не для судий единых, но на пример токмо; тожде бо и о прочиих малых, и великих, и малейших чинах годствует» (Феофан Прокопович, Слова и речи поучительные, похвальные и поздравительные, Ч. I-IV, СПб.: Сухопутный Шляхетный Кадетский Корпус, 1760-1774, II, 8). 
Подобная же сотериология, секуляризованность которой ограничена, однако, харизматическим статусом монарха (служение ему может приобретать в силу этого некоторое сходство с религиозным подвигом ${ }^{43}$ ), соответствовала позициям Петра I и в существенной степени определяла его церковную политику. Дискредитируя традиционные пути спасения и приравнивая монашество к тунеядству ${ }^{44}$, Петр несомненно и на спасение через заступничество святых, помощь чудотворных икон, молитвы юродивых и т.п. смотрел как на вредные заблуждения, отвращающие его подданных от верного служения государственным интересам. Именно эта область «незаслуженного» и «незаконного» спасения начинает при Петре пониматься как «суеверие», оказываясь приравнена тем самым к «бесовским» магическим верованиям.

Как и в других случаях, сотериологические концепции определяют особенности дисциплинарной революции. Петр стремится свести к минимуму возможность спасаться в монастырских стенах. Пути поступления в монастырь радикально ограничивается. В регламенте 1722 г. запрещается «принимать в монахи человека ниже тридесятаго года возраста» ${ }^{45}$, и при этом ищущий монашества должен быть свободен от любых обязательств в отношении государства, помещика или любого другого начальника. Принимая в монахини, нужно «смотреть на лета жены, прошло ли оной пятьдесят лет, или шестьдесят» ${ }^{46}$. Эта дискриминация женщин определяется тем, что для мужчин достаточно других оснований, чтобы не пустить их в монахи, а для женщин барьером может быть только возраст. Стоящая за этими предписаниями идея очевидна: пока человек может делать что-то полезное для государства, он не имеет права тратить время на другие занятия, включая спасение души. О спасении души заботится государство, верная служба спасает человека и спасает общество, а внешнее благочестие только отвлекает сына отечества от его подлинных задач (эта мысль проводится и в Духовном Регламенте, и в ряде других указов Петра). Монастыри не исключение, их основное дело давать приют бедным, подкидышам и отставным солдатам, на что они и получают жалованье от государства. Число монахов регулируется этой суммой ${ }^{47}$ и к спасению души отношения не имеет.

Понятно, что особенному запрету подвергается странствующее монашество, всегда вызывавшее подозрения у институциональной церкви. По инициативе Петра в 1716 г. в архиерейское обещание вставляется дополнительный

43. Cp.: E.A. Zitser, The Transfigured Kingdom: Sacred Parody and Charismatic Authority at the Court of Peter the Great, Ithaca - London: Cornell Univ. Press, 2004.

44. См. ПС3, VII, № 4450, с. 226-233 - от 31 января 1724 г.

45. Духовный Регламент Всепресветлейшего, державнейшего государя Петра Первого, императора и самодержиа всероссийского, М., 1904, с. 117.

46. Там же, с. 118.

47. J. Cracraft, The Church Reform of Peter the Great, Stanford University Press, 1971, p. 260; ПСЗ VI, № 4107, с. 782 от 12 октября 1722 г.; ср. также ПС3, VII, № 4151, с. 18 от 18 января 1723 г. 
пункт, обязывающий епископа следить, чтобы монахи не переходили из монастыря в монастырь:

Монахов содержать по положенным им правилам и уставам, не дая скитаться из монастыря в монастырь, и ниже в мирские домы, кроме собственнаго моего ведения и письменнаго соизволения ходить. ${ }^{48}$

В феврале 1718 г. издается именной указ, требующий «неистовых монахов и нищих мужеска и женска полу, которые являются в Москве и ходят по гостям и по рядам и по улицам и сидят по перекресткам и из богаделен жалованные и просят милостины по дворам и под окны: имая их, приводить по прежнему в Монастырской приказ» ${ }^{49}$. Эта тема присутствует и в позднейшем законодательстве.

Постоянному преследованию подвергаются в XVIII в. юродивые, их арестуют, их поведение расследуют, их вынуждают признаваться в корыстных мотивах своего поведения, их отправляют в монастырь под начал. Искоренением юродства занимается и сам Петр, и Феофан Прокопович ${ }^{50}$. С.А. Иванов приводит ряд примеров преследования юродства как петровского, так и послепетровского времени ${ }^{51}$. Хорошим примером может служить коломенский юродивый Василий, арестованный в $1723 \Gamma^{52}$, ходивший в стужу в одной рубахе, командовавший бесами, носивший железный посох весом в пуд; интересная деталь, о которой не упоминает Иванов, состоит в том, что духовные власти квалифицирует его как лжеюродивого, после того как он сознался, что какая-то женщина научила его натираться крапивным настоем, чтобы не мерзнуть; в результате его отослали в Юстиц Коллегию к розыску ${ }^{53}$. Примеры многочисленны; добавлю, например, сведения о «бродящем человеке Степане Меркульеве», который в 1734 г. как «якобы юродствующий и безумный» был отослан в Главную Полицмейстерскую Канцелярию ${ }^{54}$.

По этой же репрессивной схеме развивается и борьба с «суевериями». Понятие суеверия получает новый репертуар употребления. Если у Симеона Полоцкого суеверия, обусловленные недолжным почитанием истинного Бога, остаются плохо определенной и явно второстепенной категорией, возникающей прежде всего как дань томистским источникам обобщенного понятия (см. выше), то в Петровскую эпоху приоритеты меняются. Именно

48. ПС3, V, № 2985, п. 3, с. 193; ср. еще ПСЗ, VI, № 4015, с. 693, от 21 мая 1722 г.

49. ПС3, V, № 3172 , с. 576.

50. Об их отношении к юродству см.: Иванов, Блаженные похабы, с. 317-318.

51. Там же, с. 318-322; см. также А.С. Лавров, Колдовство и религия в России: 17001740 г2., М.: «Древлехранилище», 2000, с. 257-266.

52. См. о его подвигах: Иванов, Блаженные похабы, с. 319-320.

53. Описание документов и дел, хранящихся в архиве Святейшего Правительствующего Синода (ОДДС), Т. I-XLIX, СПб., 1869-1914, III, стб. 175-179.

54. ОДДС, XIV, № 280/356, стб. 383-384. 
традиционные православные верования объявляются главными суевериями и становятся основными предметами преследования. Именно они как проявления народной сотериологии, обращающейся к несанкционированным источникам спасения, оказываются в противоречии с дисциплинарным контролем. Как и колдовство и ворожба, они наделяют прибегающего к ним «незаконными» возможностями успеха, нарушающими сотериологическую монополию власти и позволяющими получить даром то, что власть дозирует по заслугам.

В Духовном Регламенте вполне отчетливо формулируется связь «суеверия» с неверным представлением о спасении, закрывающим от людей «путь истины», который должен пребывать под полным контролем власти. Дается даже своеобразная дефиниция суеверия:

[С]ловом рещи, что либо именем суеверия нарещися может, сиесть лишнее, ко спасению не потребное, на интерес только свой от лицемеров вымышленное, а простой народ прельщающее, и аки снежные заметы, правым истины путем идти возбраняющее. ${ }^{55}$

Для лучшего усвоения эта идея воспроизводится несколько раз. В начале раздела о «Делах общих» говорится:

Собственно же и прилежно розыскивать подобает оные вымыслы, которые человека в недобрую практику или дело ведут, и образ ко спасению лестный предлагают. ${ }^{56}$

Борьба с суевериями и должна, собственно, истребить «ложный образ» пути к спасению и тем самым установить сотериологическую монополию церковных и светских властей.

Первым свидетельством этой смены приоритетов могут служить изменения в архиерейском обещании. В 1716 г. по настоянию Петра в этот текст вносится статья, в которой епископ обязуется

учить и запрещать дабы расколовъ, суеверїя. и богопротивнаго чествованїя не было, дабы неведомых и от церкви несвидетелствованныхъ гробовъ за святыню не почитали. притворных беснующихъ, въ калтунах, босыхъ, и в въ рубашкахъ ходящихъ не точїю наказывать. но и градскому суду отсылать, и протчих под образомъ благочестїя притворьныхъ и прелестныхъ делъ духовънаго и миръскаго чина не принимали, дабы святыхъ иконъ не боготворили и имъ ложныхъ чюдесъ не вымышляли. ${ }^{57}$

55. Духовный Регламент Всепресветлейтего, державнейшего государя Петра Первого, c. 24 .

56. Там же, 22.

57. Живов, Из церковной истории времен Петра Великого, с. 204. 
Там, где говорится о юродивых (притворно беснующихся), петровские распоряжения повторяют в ужесточенной форме постановления Большого Московского собора 1666-1667 гг. ${ }^{58}$, в трактовке «суеверия», однако, имеют место существенные инновации.

«Несвидетельствованные гробы» и «ложные чудеса», производимые святыми иконами, представляют собой элементы нового дискурса. Под «несвидетельствованными гробами» понимаются мощи местночтимых святых, еще не канонизированных церковью; местное почитание мощей неизбежный момент в становлении культа новых святых; поэтому запрет на эти «гробы» фактически означал запрет на почитание новых подвижников. Равным образом и «ложные чудеса» - это просто новые чудеса по преимуществу с новыми (неизвестными прежде в качестве чудотворных) иконами; запрет на «ложные чудеса» фактически означал запрет на новые чудотворные иконы. Таким образом, понятие суеверия расширяется, охватывая вполне традиционные православные религиозные практики, вступающие в противоречие с петровской рационализацией.

Развитие этой дисциплинарной парадигмы находим в основном памятнике петровской церковной политики, а именно в Духовном Регламенте. Между этим текстом и архиерейским обещанием имеется прямая связь. В одном из пунктов «Дел общих» об иконопочитании говорится: «О иконах святых смотреть того, что во обещании поставляемых Епископов написано» ${ }^{59}$, а среди «дел епископов» указывается:

Смотрети же должен Епископ, чего смотреть обещался с клятвою на своем поставлении, <..> дабы иконам Святым ложных чудес не вымышлено; також о кликушах, о телесах мертвых несвидетельствованных, и прочих всего того добре наблюдать. ${ }^{60}$

Осуждение нерациональных практик повторяется по нескольку раз, причем порою им приписываются корыстные мотивы. Так, в разделе о посещении архиереями своей епархии читаем:

Спросит же Епископ священства и прочих человек, не делаются ли где суеверия? Не обретаются ли кликуши? Не проявляет ли кто для скверноприбытства ложных чудес при иконах, при кладезях, источниках? и прочая. И таковыя безделия запретит, со угрожением клятвы на противляющихся упрямцов. ${ }^{61}$

58. О преемственности в процессе дисциплинирования, см.: Лавров, Колдовство $u$ религия в России: 1700-1740 г2., с. 399-408.

59. Духовный Регламент Всепресветлейшего, державнейшего государя Петра Первого, c. 23 .

60. Там же, с. $30-31$.

61. Там же, c. 41. 
Точно так же повторяется и тема мощей, ср.:

О мощах святых, где какия явятся быть сумнительныя, розыскивать: много бо и о сем наплутано. ${ }^{62}$

Об этих традиционных православных практиках говорится в одном ряду с осуждением «народных» религиозных обычаев, осуждавшихся церковью как неправославные в течение столетий, например, веры в двенадцать пятниц ${ }^{63}$ :

Например, не делать в пяток и празднованием проводить, и сказуют, что пятница гневается на непразднующих, и с великим на оных же угрожением наступает. Також поститися некиих имянных дванадесять пятниц, а то для многих телесных и духовных приобретений; також собственно, аки важнейшия паче иных времен, службы почитать, Обедню Благовещенскую, Утреню Воскресенскую и Вечерню Пятьдесятницы. ${ }^{64}$

О том, как мог развиваться конфликт между центральной властью, занятой дисциплинированием, и православным населением, преданным традиционным религиозным практикам, свидетельствует следующая история. В 1723 г. черниговский епископ Иродион послал в Синод доношение, в котором он сообщал, что 5 марта поп Терентий, служивший в церкви Вознесения Господня, донес ему, что образ Богоматери испускает слезы, которые видел не только он, Терентий, но и «знатные люди». Епископ Иродион знал, что такие чудеса бывают, и послал двух иеромонахов разобраться с этим чудом. Иеромонахи обнаружили на иконе влажные следы от слез и сосудец, в который были собраны пролившиеся слезы. Икону перенесли в кафедральный собор и на следующий день она даже совершила чудо исцеления с черниговской жительницей Авдотьей Исаковой дочерью, у которой внезапно начало «корчити уста и руки и ноги». По указанию епископа «оная жена духовнику на исповеди о случае сем сказала» ${ }^{65}$. В своих действиях епископ следовал издавна принятому порядку.

У Синода, однако, был другой порядок. В канцелярии к сообщению Иродиона выписали два пункта из Духовного Регламента (цитировавшихся

62. Там же, с. 23.

63. Об апокрифическом тексте, лежащем в основе этого поверья, см.: А.Н. Веселовский, « Опыты из истории развития христианской легенды, IV, Сказание о 12-ти пятницах», Журнал Министерства народного просвещения, 1876, июнь, с. 326-367; о фольклорной рецепции этой традиции: С.М. Толстая, «Следы древнеславянской апокрифической традиции в полесском фольклоре: “Сказание о 12 пятницах", in C.М. Толстая, Полесский народный календарь, М.: «Индрик», 2005, с. 543-562.

64. Духовный Регламент Всепресветлейшего, державнейшего государя Петра Первого, c. 22 .

65. Полное собрание постановлений и распоряжений по ведомству православного исповедания (ПСПР), Т. I-X, СПб., Пг., 1869-1916, IV, № 1323, с. 168 - 15 июня 1724 г. 
выше), требовавшие, чтобы епископы преследовали недолжное почитание икон и не объявляли их чудотворными «для вспоможения церквей убогих, или новых построения» ${ }^{66}$. Основываясь на этом нормативном документе, Синод определил образ и истекшие от него слезы «убрав в удобный тому ковчег и, запечатав, прислать». Было приказано и попа Терентия немедленно «выслать под крепким караулом» ${ }^{67}$. Сношения, высылка и разбирательство заняли некоторое время, так что Петр Великий успел скончаться, что, видимо, и обусловило сравнительную мягкость вынесенного 25 августа 1725 г. приговора. На попа Терентия было оказано давление, и он дал показания, чтобы избавиться от бесконечного и тягостного пребывания в тюрьме под следствием. Он показал то, что от него требовали, а именно что «таких слез подлинно не было, а умыслил де он то разгласить в народ ложно для собственного своего прибытку». Синод

для помяновения высокославныя и вечнодостойныя памяти Государя Императора снисходительное милосердие показуя, согласно приговорили: по силе имянного Императорскаго Величества $<\ldots>$ указа, по которому велено разглашающим <..> чудеса притворно $<\ldots>$ или подобное тому творящим суеверие чинить наказание и вечную ссылку на галеры с вырезанием ноздрей ${ }^{6}$, облехча оное публичное наказание, выбить его Терентья плетми и, вместо вечной на галеру ссылки, лишить его священства. ${ }^{69}$

Наказаны должны были быть и те, которые «видели иные слезы текущия, а иные крапли каплящыя»; их должны были «публично бить плетми ж нещадно» и в течение месяца по воскресным дням им предписывалось стоять у церквей и виниться, «оную совершенноую ложь изъявляя». У Иродиона указано было «взять из собственных его архиерейских имений штрафа тысячу рублев, не взирая ни на какия его отговорки, без всякаго отлагательства, которые и прислать в Святейший Синод немедленно» ${ }^{70}$. Все это следовало сделать, «дабы и впредь, на то взирая, другим так чинить неповадно было» ${ }^{71}$.

В течение всего XVIII в. государственная борьба с «суевериями» то стихала, то нарастала вновь. Тем не менее она оставалась существенным элементом

66. Духовный Регламент Всепресветлейшего, державнейшего государя Петра Первого, c. 23

67. ПСПР, IV, № 1323, c. 174.

68. Имеется в виду резолюция Петра I на докладных пунктах Синода от 12 апреля 1722 г. В докладных пунктах говорилось: «Когда кто велит для своего интереса, или суетной ради славы огласить священником какое чудо притворно и хитро чрез кликуши, или чрез другое что, или подобное тому прикажет творить суеверие». В резолюции Петра предписывалось: «Наказанье и вечную ссылку на галеры с вырезанием ноздрей» (ПС3, VI, № 3963, с. 652).

69. ПСПР, V, № 1639 , с. 169.

70. Там же.

71. Там же, с. 170. 
государственной политики. Так, в 1751 г. была признана чудотворной Ахтырская икона Божией Матери, обнаруженная местным священником еще в 1739 г., но переданная им в храм лишь через три года, в царствование относительно благочестивой Елизаветы Петровны. Икона была признана чудотворной после работы нескольких следственных комиссий и чудесного явления Богородицы влиятельной баронессе фон Вейдель ${ }^{72}$. Было бы поспешно делать из этого единичного случая вывод о наступившем со времен Елизаветы либерализме. В 1766 г. новгородский митрополит Димитрий (Сеченов) распоряжается наложить наказания на всех, участвовавших (явно без всякой корыстной цели) в прославлении в качестве чудотворной иконы Иоанна Златоуста в погосте Михайлове Бежецкой пятины. Жители погоста, включая князя Василия Мещерского, попа Ивана Мокеева и диакона Григория Федорова построили часовню и служили молебны. За это поп и дьякон были посланы (за разглашение ложных чудес) на три года в монастыри в работу на покаяние, дьячек и понамарь - на год, князя Мещерского отлучили от причастия на два года, приказчика Петра Замятина - на три года; девка Акилина при собрании мирском наказана плетьми ${ }^{73}$.

Дисциплинарная революция включает, как и в XVII в., упрочение покаянной дисциплины, утверждение церковного покаяния как институализованного инструмента спасения в противность традиционным надеждам на то, что можно было назвать «незаконным» спасением. Для Петровской эпохи это выглядит несколько парадоксально, поскольку никакого стремления к благочестию у Петра не было никогда и воспитание населения в уважении к церковным институциям в его планы явно не входило. Тем не менее Петр требовал регулярной (ежегодной) исповеди, хотя это требование не было частью никакой программы религиозного обновления или возрождения. В этом плане петровские указы отличаются от сходных предписаний церковных реформаторов (ревнителей благочестия, патриархов XVII столетия, участников Московского собора 1666-1667 гг.). Церковные реформаторы стремились создать новое благочестие, более тесно связанное с институализованной церковью, чем традиционное. Петр был безразличен или враждебен к благочестию любого типа, его волновали контроль и дисциплина как таковые. Можно сказать, что устрожение покаянной дисциплины было для Петра вторичным результатом политики финансового и поведенческого контроля.

8 февраля 1716 г. Петр издает указ, который обязывал старообрядцев «записываться в раскол»; они должны были регистрировать свой конфессиональный нонконформизм и платить двойной налог ${ }^{74}$. Эта мера была в большой степени фискальной; она вписывается в набор разнородных

72. Ср.: ОДДС, ХХХІІ, № 189/205, стб. 481-483 - 31 августа 1752 г.; ср.: История явления Ахтырской чудотворной иконы Богоматерин соборного Покровского храма, где она ныне находится, СПб., 1903.

73. ОДДС, L, № 130/381, стб. 170-171 - 23 Марта 1770 г.

74. ПСЗ, V, № 2991, с. 196. 
государственных актов, направленных на увеличение доходов казны; последствия, однако, были куда более глубокими. Указ означал определенную легализацию старообрядчества (поскольку «раскольники» могли с помощью двойного налога купить нечто вроде легального статуса, хотя преследование старообрядцев не прекращалось до конца царствования Петра) и служил стимулом для его конфессионализации. Конфессионализация старообрядчества ${ }^{75}$ автоматически порождала аналогичный процесс и среди той части православного населения, которая признавала официальную церковь; конфессионализация сопровождалась религиозным дисциплинированием.

Старообрядцы в силу естественных причин предпочитали не платить двойного налога, поэтому возникала задача обнаружить скрытых старообрядцев. С этой целью Петр издал указ от 17 февраля 1718 г. (и ряд позднейших дополнений к нему). Указ требовал, чтобы

все вышеписанные люди [«разночинцы и посадники и поселяня» - В.Ж.] в господские праздники и в воскресные дни ходили в церковь Божию к вечерни, к завтрене, а паче же ко святои литургии $<\ldots>$ и по вся б годы исповедывались. И то надзирать в приходех самим священником и прикащиком, и старостам, где случитца. И кто будет исповедыватца и не исповедыватца, тому всему иметь книги погодно и присылать их по епархиам в духовные приказы, и кто по тем книгам явитца без исповеди, и с таких править тех приходов священником штрафы. ${ }^{76}$

Ежегодная исповедь и регистрация этого акта в исповедных книгах должны были стать инструментом, который позволил бы властям отделить старообрядцев от приверженцев официальной церкви и исключить возможность ухода от двойного налогообложения.

Это стало началом длительной игры в кошки-мышки, в которой одна сторона постоянно совершенствовала методы детекции, а другая сторона в ответ изобретала новые способы сокрытия. Характер доступных нам данных не дает возможности решить, кто был победителем в этой борьбе, продолжавшейся в течение всего XVIII в. Так, старообрядцы давали взятки, чтобы приходские священники записали их как исповедников и скрыли тем самым их принадлежность расколу. В ответ Синод обязал церковников и прихожан доносить на священника, записывшего в исповедные книги лиц, которых никто не видел за исповедью. Донос и последующее наказание были серьезной угрозой, которая могла бы остановить священника от незаконных действий, но нетрудно было найти и другое решение. Прихожанин или прихожанка объявляли, что они больны и звали священника домой для предсмертной исповеди. Потом они выздоравливали, но у священника были законные основания записать их в исповедные книги, хотя никто не вдел их

75. Об этом процессе, см.: Лавров, Колдовство и религия в России: 1700-1740 г2., с. 60-74.

76. А.А. Преображенский, Т.Е. Новицкая, ред., Законодательство Петра I, М.: Юрид. лит., 1997, с. 538-539. 
споведающмися. Правительство узнало и об этой хитрости и потребовало, чтобы свидетель присутствовал и при исповеди на смертном одре ${ }^{77}$. Это, однако же, означало, что уклоняющемуся от исповеди нужно было дать взятку не только попу, но и свидетелю. Дошедшие до нас документы говорят, конечно, о тех случаях, когда обман был раскрыт. Можно предположить, что в большинстве случаев все сходило с рук благополучно, но эти случаи не отражены ни в каких документах и не поддаются статистической оценке. Именно поэтому мы и не знаем, кто победил в этом состязании. Чем строже становился государственный контроль, тем недостоверней делались документы; они вовлекались в порочный круг обмана ${ }^{78}$.

Петр безусловно знал о предшествующих попытках ввести регулярную исповедь; в этих условиях нельзя не рассматривать петровские инновации как продолжение существовавшей традиции. Петр скорее всего осознавал эту преемственность и интерпретировал ее в свою пользу. Как говорилось выше, в XVII столетии светская и духовная власть конкурировали за право контролировать религиозную жизнь населения. Петр наконец выиграл это соревнование и, издавая указы 1716 и 1718 гг, мог с полным правом рассматривать себя как победителя. Но даже и в этом качестве он оказывался продолжателем не только усилий своего отца, но и усилий противоположной партии (патриархов Никона, Иоакима и Адриана), которых царь считал врагами государства. Вне зависимости от исходного предназначения ежегодной исповеди эта мера, проведение которой в жизнь было поручено духовенству, неизбежно приобретала религиозное значение и воспринималась как еще один шаг в политике установления религиозной дисциплины.

Именно так эта мера выглядит в таком важнейшем памятнике петровского дисциплинирования, как «Последование о исповедании» Гавриила Бужинского 1723 г. ${ }^{79}$ Здесь подробно говорится о суевериях как грехах, требующих покаяния, в целом совершенно в том же духе, что и в Духовном Регламенте. Особенность данного памятника состоит в том, что - в соответствии с его основным содержанием - в нем делается акцент на правильной покаянной дисциплине, которая противополагается «суеверным» надеждам спастись на любых других окольных путях. Так, здесь имеется рассуждение о том, что против первой заповеди согрешает тот, «хто святыхъ угодников божїихъ равно божескою честїю почитаетъ, и на нихъ во всякомъ своемъ добре

77. ПСЗ, VI, № 4022, ст. 15, с.705; Духовный Регламент Всепресветлейшего, державнейшего государя Петра Первого, с. 110; С.И. Смирнов, Древне-русский духовник: Исследование по истории церковного быта, Чтения в Имп. Обществе истории и древностей российских, 1914, кн. 2, III, Исследования, I-VIII, с. 238.

78. См. подробнее: V. Zhivov, "Handling Sin in Eighteenth-Century Russia", in Andrew Kahn, ed., Representing Private Lives of the Enlightenment, Oxford: Voltaire Foundation, 2010, p. 123-148 [Studies on Voltaire and the Eighteenth Century, 2010: 11].

79. В приложении к этому изданию перепечатывается раздел Духовного Регламента о должности священнической, [Гавриил Бужинский], Последование о исповедании, М.: Московская типография, 1723, л. 34-49об. 
здешномъ и будущем надеетца такъ, какъ на самаго бога» ${ }^{80}$. Вместо «незаконной» надежды на святых предлагается регулярная исповедь (сакраментальное покаяние). Священник должен был выяснить у исповедающегося, повсегодно ли он исповедался; «Аще не повсегодно. длячего такъ нерадилъ о твоемъ спасенїи; А въ правилахъ отеческихъ написано: хто не исповедается за леностїю на всякой годъ, тотъ недостоитъ христїаниномъ называтца» ${ }^{81}$. Сотериологический контроль и здесь оказывается важнейшей задачей религиозной политики, а регулярная исповедь выступает как дисциплинирующая практика, основанная на религиозной доктрине.

\section{Неудачи русской дисциплинарной революции}

Русская дисциплинарная революция XVIII в. кончается полным провалом. Власть вынуждена отступить даже в таком деле, в принципе поддающемся регламентации, как ежегодная исповедь. Лишь к концу этого столетия принуждение к исповеди перестало быть насильственным, а штрафы за неисповедь были отменены ${ }^{82}$. Ощутимого результата это не дало: подавляющее большинство населения продолжало верить так, как оно верило и раньше, и это было характерно едва ли не для всех социальных групп (видимо, с некоторыми вариациями в степени): вельможи могли так же пригревать бродячих монахов, как и непросвещенные крестьяне, а получившие семинарское образование священники также поклоняться несанкционированной чудотворной иконе, как провинциальный купец. Возможности государственного контроля были ограниченными, а население умело находило способы его обходить; это умение превращалось в один из важнейших социальных навыков.

Нет смысла сводить причины провала русской дисциплинарной революции к какому-либо одному фактору. Скорее, как это часто бывает в истории, здесь действовало сразу несколько причин, накладывавшихся друг на друга. С одной стороны, православная сотериология существенно отличалась от западной. Как отмечал Питер Браун, на Западе спасение было несравненно более институализовано, чем на Востоке. Спасение обеспечивал не тот, кто обладал на это институциональной санкцией (священным чином), а тот, кто плохо поддающимся рационализации образом являет особые благодатные дары $^{83}$. Конечно, у кальвинистов, о которых пишет Ф. Горски, клерикальные структуры не играют той роли, что у католиков, но спасение оказывается еще более институализованным. Кальвин учит о предестинации к спасению; реализация этого предопределения осуществляется в общине, которая

80. Там же, л. 11.

81. Там же, л. 6-6об.

82. См.: Zhivov, "Handling Sin in Eighteenth-Century Russia", p. 146.

83. P. Brown, Society and the Holy in Late Antiquity, Berkeley - Los Angeles: Univ. of California Press, 1982, p. 166-195. 
эффективно следит за соответствием поведения его члена его предназначению и навязывает моральные нормы поведения как предопределенным к спасению, так и предопределенным к погибели.

В России XVIII в. государство и церковь пытаются взять спасение под свой контроль, но им это не удается. Неинституциональные способы спасения остаются для большинства православных более привлекательными, чем институциональные, контролируемые государством. Спасение могло быть достигнуто с помощью «святых людей», чудотворных икон, святых колодцев и т.д. В XVIII в. предпринимались попытки осудить это «незаконное» спасение и исключить его из числа допустимых инструментов православного благочестия. Чрезвычайно показательно, что эти усилия не принесли результатов. Для большинства населения малоизвестная чудотворная икона или подозрительный юродивый оставались куда более действенными и надежными способами избежать вечных мук, чем признание в не вполне понимаемых прегрешениях, произнесенное пред приходским священником, и отпустительная формула, связанная с еще менее понятной властью ключей. В этих условиях церковная власть была вынуждена идти на компромиссы и признавать то, что при Петре I или Екатерине II считалось бы «суеверием». В условиях распадающихся традиций «непросвещенное» благочестие было лучше, чем отчуждение от церкви, и в силу этого духовенство если и не поощряло «суеверные» практики, то относилось к ним с терпимостью. Юродивых перестали отправлять в застенок, а открытие чудотворной иконы больше не влекло за собой пристрастного разбирательства. В подобных обстоятельствах народная религиозность оставалась - и в императорский период и, с теми или иными оговорками, вплоть до сегодняшнего дня - традиционной и по существу нереформированной ${ }^{84}$. Это имело многочисленные последствия и для религиозной жизни русского общества, и для моделей его культурного поведения.

Другой и никак не менее важный момент состоит в том, что власть берет религиозное дисциплинирование в свои руки. Это немедленно превращает данный процесс в один из феноменов чистого принуждения, которое вызывает в обществе отторжение и протест. Нельзя сказать, что момент государственного принуждения полностью отсутствовал в религиозном дисциплинировании, например, в католической Германии времен Контрреформации ${ }^{85}$. С самого начала, однако, это принудительное дисциплинирование сочеталось там с духовной реформой, выдвигавшей на первый план индивидуальную религиозную чувствительность, которая и легла в основу нового католического благочестия (вопрос о том, какая пропорция населения была затронута

84. Cp.: G. Freeze, "Institutionalizing Piety: the Church and Popular Religion, 1750-1850", in J. Burbank and D.L. Ransel, eds., Imperial Russia: New Histories for the Empire, Bloomington - Indianapolis: Indiana Univ. Press, 1998, p. 210-249; S. Dixon, "Superstition in Imperial Russia”, in S.A. Smith and Alan Knight, eds., The Religion of Fools? Superstition Past and Present, Oxford - New York: Oxford Univ. Press, 2008, p. 207-228 [Past and Present Supplements, Supplement 3, 2008].

85. Myers, "Poor, Sinning Folk", p. 116-123. 
духовной реформой, остается дискуссионным, однако очевидно, что католическая Европа существенно опережала в этом отношении Россию). Петр ни к какому обновленному благочестию не стремился. Вообще, для русских властей дисциплина была несравненно важнее каких-либо религиозных ценностей. Поэтому никакой интериоризации дисциплинарных ценностей не происходило, а реакция населения состояла в основном в изыскивании способов избежать государственного контроля и скрыться от принудительного надзора. В своей дисциплинирующей деятельности власть не искала и не находила никаких добровольных сотрудников. Вместо воспитания сознательных подданных и консолидации общества политика дисциплинирования лишь усиливала отчуждение населения от власти. Отказ от этой политики, однако, освобождал не самодеятельное общество, а разобщенные социальные группы, не связанные общими ценностями. Именно это культурно фрагментированное общество оказывается результатом провала дисциплинарной революции ${ }^{86}$.

Université de Berkeley

zhiv@berkeley.edu

86. В недавней монографии М.Д. Долбилова мои выводы рассматриваются как слишком радикальные: наряду с «провалами» были, на взгляд автора, и кое-какие успехи. Как пишет Долбилов, комментируя мои заключения, «можно согласиться с выводом автора о том, что государственное религиозное дисциплинирование в XVIII веке не было успешным как проект трансформации массовой православной религиозности, но применение с конца XVIII века сходной модели конфессиональной политики к другим вероисповеданиям едва ли дает основание говорить о полном “провале”» (М.Д. Долбилов, Русский край, чужая вера: Этноконфессиональная политика империи в Литве и Белоруссии при Александре II, М.: Новое литературное обозрение, 2010, c. 766). С этой оговоркой я, пожалуй, готов согласиться: с католиками и протестантами российские власти справлялись лучше, чем с православным населением. Стоит отметить, однако же, что успех или не успех государственного дисциплинирования зависит не только от того, какими качествами обладает эта политика, но и от того, кто оказывается ее адресатом. «Провалы» были хотя бы отчасти обусловлены, как я пытался показать, и сотериологическими представлениями этого адресата. Нет сомнений, что католики и протестанты исходили из других сотериологических представлений, что, я бы думал, способствавало их податливости.

М.Д. Долбилов говорит и о том, что «и в отношении православия XIX век принес более гибкие приемы государственного дисциплинирования, основанные на взаимодействии с хотя бы ограниченной инициативой клира и “низовым” благочестием мирян» (там же). Можно, видимо, согласиться и с этим, хотя оценка результатов всегда субъективна. Отдельные островки реформированного православия в XIX в. несомненно появлялись, но, на мой взгляд, они отнюдь не обеспечивали той интериоризации религиозной дисциплины, которая характеризовала описанные Ф. Горски общества. Достаточно вспомнить о распространении в XIX-начале XX в. антиинституционального сектантства (например, штундизма), чтобы «провалы» православного дисциплинирования перестали казаться преувеличением. 